Session 1793

\title{
Transforming First Year College Experience Through A Unique Learning Community
}

\author{
Sudhir Mehta, Kathy Enger \\ North Dakota State University
}

\begin{abstract}
Education researchers, independent policy-making bodies, and several high level commissions on higher education recommend that colleges and universities need to strengthen the quality of their graduates in regards to leadership skills, problem-solving ability, communication skills, and citizenship.

This paper describes a unique learning community program that has been implemented from Fall 2003 to meet the above challenges. The Archibald Bush Foundation provided a three-year grant to partially fund the program. The freshmen program, within a caring environment, integrates development of leadership, communication, and problem-solving skills, and service learning. The program has a strong assessment component with most of the testing being done in April 2004. The presentation at the conference will describe this unique learning community program and the assessment results.
\end{abstract}

\section{Problem}

Education researchers, independent policy-making bodies and several high level commissions on higher education indicate that a large percentage of students (40-50\%) drop out of college at a time when the importance of attaining a college degree has never been higher. For those students who do graduate, concerns are raised regarding their ability to write clearly, speak effectively, think logically, critically, and across disciplines, and to participate in a democratic society with civic responsibility ${ }^{1-11}$.

\section{Hypothesis}

Faculty and staff in academic affairs and student affairs at NDSU will enhance the quality of student education and improve retention rate by building learning communities, implementing a practice-oriented curricula, and incorporating leadership and service learning into residential and classroom settings. 


\section{Goals}

Our goals are to integrate learning communities, problem-based learning, and leadership development in the first year curriculum.

- Learning Communities

Since education is a social process deeply rooted in the understanding of community and democracy, learning communities will address both the social and academic needs of students. Faculty and staff at NDSU will create collaborative and cohesive learning environments whereby students may develop a sense of place and form small communities within the larger university context. Research has shown that attrition diminishes in proportion to students' sense of community, participation, and involvement in campus life, particularly during the freshman year.

- Problem-Based Learning Prepare students carefully and comprehensively for whatever may lie beyond graduation by providing opportunities to learn through inquiry rather than simple transmission of knowledge; analyzing and solving open-ended, real-world problems; working cooperatively in teams; and communicating effectively, verbally and in writing.

- Leadership Development

Create a highly effective environment for the development of individuals by integrating theory and practice of effective leadership into curricula. Students will demonstrate leadership talents and attitudes through active participation in service learning and will be empowered to become effective agents of social change.

\section{Action Plans}

The activities that will be carried out during the three years are listed below. Most of these activities have already begun since Spring 2003, as the first batch of students joined in Fall 2003.

- Consulting with national leaders in the areas of learning communities, problem-based learning, leadership development, assessment, and evaluation.

- Training team coordinators in the areas of learning communities, problem-based learning, and leadership development. They will in turn develop training materials for other team members, instructors, faculty advisors, and student affairs staff who are participating in this project.

- Conducting workshops for instructors, faculty advisors, student affairs staff, and student mentors.

- Randomly selecting a cohort of 25 students from a group of freshmen in a particular discipline who have volunteered to participate in this project. Four, eight, and sixteen cohorts will be selected in the first, second, and third year of the grant respectively. Each cohort will be residing in a close proximity (not as roommates) within in a residence hall.

- Forming learning communities, each one consisting of a group of 25 students, one faculty advisor, other instructors who are teaching this group of students, student affairs staff and student mentors. Each cohort will take two gateway classes together per semester during their freshman year.

Proceedings of the 2004 American Society for Engineering Education Annual Conference \& Exposition Copyright (C2004, American Society for Engineering Education 
- Planning academic and social activities for each community within and outside the classroom.

- Integrating problem-based learning, leadership development, and service learning into the courses freshmen take together.

- Interacting with student mentors, who will provide social and academic support.

- Continuing with problem-based learning curricula in many classes beyond freshman year, as 105 faculty members (out of 500) at NDSU have already been trained in problembased learning.

- Assessing student learning, problem solving, and leadership skills using pre- and post local and national surveys and standardized tests.

- Disseminating the results of the CCLP initiatives to interested faculty members from NDSU and other regional and national colleges and universities. The information dissemination coordinator and other team members will also present workshops and papers at regional and national conferences and submit papers for publication to refereed higher education journals.

- Evaluating the project through the formative and summative assessment with the help of the Office of Institutional Analysis at NDSU and the Higher Education Research Institute at the University of California at Los Angeles. The Faculty Development Committee of the University Senate will independently evaluate the CCLP Project and the assessment data annually. The Committee's report, highlights of yearly activities, and the assessment results will be reported to the Bush Foundation annually.

- Institutionalizing the CCLP Project after the granting period is completed, with the support of NDSU administration and by hiring a full time project manager.

- Becoming a national model for a reconsidered role of higher education in society.

\section{Outcomes}

The specific outcomes of the project are listed below.

- Increase student retention rate by $10 \%$ by the third year of the project.

- Increased overall grade point average (assumed to be among the project participants compared to control group students).

- Increased student abilities to define problems, participate in the overall learning experience, and solve problems.

- Increased student college level reading, critical thinking, writing, and mathematics.

- Increased student understanding of self, sense of personal ethics, and clarity of personal values.

- Increased student commitment to civic responsibility, participation in volunteer or community service, and multicultural awareness.

- Increased student understanding of and commitment to leadership.

- Increased student understanding of emotional intelligence factors, such as knowing and managing one's emotions, motivating oneself, recognizing emotions in others, and handling relationships.

- Increased sense of satisfaction by faculty in educating students.

- Increased collaboration between academic and student affairs.

Proceedings of the 2004 American Society for Engineering Education Annual Conference \& Exposition Copyright (C2004, American Society for Engineering Education 
- Increased acceptability of the CCLP concepts among various disciplines within higher education.

- Adaptation of this project or certain aspects of it by faculty members at other institutions.

\section{Assessment Plans}

Assessment of student learning is an important part of this project. Variables to be assessed include grade point average, retention, and graduation data from the experimental and control groups. An additional measure of student learning will be obtained using a standardized test, The Academic Profile of the Educational Testing Service. The Academic Profile is a wellestablished, well-researched instrument for measuring several aspects of general education, including college-level reading, critical thinking, writing, and mathematics in the context of material from the humanities, social sciences, and natural sciences.

Leadership will be assessed through selected questions from the Cooperative Institutional Research Program's (CIRP) Freshman Survey and the Your First College Year (YFCY) from the Higher Education Research Institute (HERI), as well as the BarOn Emotional Quotient Inventory. Other values, (i.e., understanding self, ability to set goals, and clarity of personal values), beliefs, and attitudes will also be measured using the CIRP and the YFCY surveys.

\section{Dissemination Plans}

The results of the project will be disseminated through regional faculty development workshops that focus on the new integrated approach and its effects on students. These workshops will be organized through the Collaboration for the Advancement of College Teaching \& Learning, a regional organization that supports and promotes outstanding college teaching at public, private, and tribally-affiliated colleges and universities. The project coordinators will also present papers at regional and national conferences and submit papers for publication to refereed higher education journals.

\section{Three main issues that will be addressed during the presentation are}

1. The need for transforming college education that integrates development of leadership, communication, problem-solving skills, and service learning in a caring environment.

2. Our learning community program for transforming college education that has integrated development of leadership, problem-solving, and communication skills.

3. Initial results of implementing the above program and the future plan.

\section{Bibliography}

1. American Association for Colleges and Universities. (2002). Greater expectations: A new vision for learning as a nation goes to college. Retrieved September 10, 2003 from http://www.greaterexpectations.org.

2. Astin, A.W., \& Astin, H. S. (2000). Leadership reconsidered: engaging higher education in social change. Battle Creek, Michigan: W.K. Kellogg Foundation. 
3. Carnegie Foundation for the Advancement of Teaching. (1998). Reinventing undergraduate education: A blueprint for America's research universities. Retrieved February 6, 2002, from http://notes.cc.sunysb.edu/Pres/boyer.nsf.

4. Boyer, E. L. (1990). Scholarship reconsidered: Priorities of the professoriate. Princeton: Carnegie Foundation for the Advancement of Teaching.

5. Colby, A., et. al. (2003). Educating Citizens: Preparing America's Undergraduates for Lives of Moral and Civic Responsibility. San Francisco: Jossey-Bass.

6. Ehrlich, T. (2000). Civic Responsibility and Higher Education. Westport: Oryx Press.

7. Kellogg Commission on the Future of State and Land Grant Universities. (1997). Returning to our roots: The student experience. Washington, D. C.: National Association of State Universities and Land Grant Colleges.

8. National Institute of Education. (1984). Study group on the conditions of excellence in American higher education. In Involvement in learning: Realizing the potential of American higher Education. Washington, D. C.: U.S. Department of Education.

9. National Research Council. (2000). How people learn: Brain, mind, experience, and school (expanded edition). National Research Council's Commission on Behavioral and Social Sciences and Education. National Academy Press, Washington, DC. Retrieved March 30, 2001 from http://books.nap.edu/catalog/9853.html

10. National Research Council. (2001). Knowing what students know: The science and design of educational assessment. National Academy Press, Washington, DC. Retrieved May 5, 2002 from http://www.nap.edu/catalog/10019.html

11. Smith, B. \& McCann, J. (2001). Reinventing ourselves: Interdisciplinary education, collaborative learning, and experimentation in higher education. Bolton, MA: Anker Publishing.

\section{Biographies}

Sudhir Mehta is the Associate Vice president for Academic Affairs and Professor of Mechanical Engineering. He has been at NDSU since 1984. He is currently the director of the learning community project and was the director of the Faculty Institute for Excellence in Learning (FIEL) for implementing campus-wide training program on cooperative and problem-based learning. His areas of interest are enhancing student learning, measurements, controls, robotics, mechanics, design optimization, and machine vision. He has co-authored two CD-ROM's containing hypermedia based instrumentation and communication resource modules, and their work "Statics: The Next generation" is published by Prentice Hall in 2001. He has also developed innovative techniques for active learning, collaborative learning, and quick assessment. He and his colleagues have received several grants from the NSF, Bush Foundation, 3M, and HP to enhance student learning. In 2002, Dr. Mehta received the fellow grade from the American Society for Engineering Education (ASEE), Teacher of the Year award from the NDSU College of Engineering and Architecture's, and the Faculty Lectureship Award at NDSU. Earlier, he was named "The 1997 North Dakota Professor of the Year" by the Carnegie Foundation and has received the Peltier Award for Innovative Teaching from NDSU in 2000. He has also received the HP Award for Excellence in Laboratory Instruction in 1999. Dr. Mehta and his colleagues have received the best paper/presentation awards from the ASEE in 2001, 1999, and 1995. Dr. Mehta received the Carnot Award for the best teacher of the year, four times, from the students of Pi Tau Sigma Society.

Kathy Enger is a social sciences librarian at NDSU. She has a doctorate degree in Educational Leadership/Higher Education from the University of North Dakota and holds a Master's degree in Library and Information Science from the University of Iowa. Her dissertation examined the literature of higher education to determine how the literature reflects the discipline's development and practice. Through her work at North Dakota State University, she participated in the creation of a unique learning community that integrates service learning with leadership development and problem-based learning methods for undergraduates. Using the Kellogg transformational leadership model as background material for student leadership development, she is currently studying the theories and practices of John Dewey, Jane Addams, Paulo Freire, and bell hooks to support the model. She teaches in the University Studies program and works as social sciences librarian at the university. 